MATEC Web of Conferences 3, 01040 (2013)

DOI: $10.1051 /$ matecconf/20130301040

(C) Owned by the authors, published by EDP Sciences, 2013

\title{
Experimental determination of liquid-liquid equilibrium data and their representation using the UNIQUAC and NRTL equations
}

\author{
S. Ghizellaoui ${ }^{1}$, and C. Coquelet ${ }^{2}$ \\ ${ }^{1}$ Département de Chimie Industrielle, Université de jijel, BP 98 Ouled Aissa 18000 Jijel, Algérie \\ ${ }^{2}$ Centre énergétique et procédés, MINES Paris Tech, 35, rue Saint Honoré 77305 Fontainebleau, France
}

Knowledge of physical and chemical data is essential in process engineering, including the fluid phase equilibria, important phenomena for the design and simulation of many separation processes such as distillation and liquidliquid extraction. One important information concerns the phase diagram.

Many researches [1-4] have investigated multicomponent systems in order to understand and provide further information about the thermodynamic properties of such systems and representation of phase equilibria.

In this study an apparatus has been specially developed and implemented, it is based on a «staticanalytic » method (similar to the one of Laugier and Richon [5]) with two liquids phase samplers in order to determine experimental «liquid - liquid» equilibrium data [6] ; mixtures of known overall composition were prepared directly inside the equilibrium cell. The analytical work was carried out using a Perichrom (France) gas chromatograph equipped with a thermal conductivity detector (TCD) connected to a data acquisition system.

The need to acquire good «liquid - liquid» equilibrium data is important, but it is also essential to be able to represent accurately using appropriate models and thus be able to calculate the phase equilibria in all conditions of use, for this the Simulis software from Prosim (Toulouse, France) is used with the NRTL [7] (Non Random Two Liquids) and UNIQUAC [8] (Universal Quasi Chemical) activity coefficient models to correlate the experimental data

In this study the results for the systems (water- 1propanol- 1-pentanol) and (water- ethanol- 1-pentanol) were considered. The reliability of the experimental data obtained was successfully verified by applying the Othmer-Tobias [9], Bachman [10] and Hand [11] correlations.

\section{References}

1. J.T. Chen, Y.M. Lin, Fluid Phase Equilibria 259189 (2007)

2. A. Chafer, J.de la Torre, R. Muno, M.C. Burguet, Fluid Phase Equilibria 23872 (2005)
3. I. Kirbaslar, S. Cehreli, D. Ustun, E. Keskinocak, Braz. J. Chem. Eng. 17(2) (2000)

4. I. Ashour, S.I. Abu-Eishah, J. Chem. Eng. Data. 51 859 (2006)

5. S. Laugier, D. Richon, Rev. Sci. Instrum. 57469 (1986)

6. J.D. Raal, A.L. Muhlbauer, Phase Equilibria: Measurement and Computation, Taylor \& Francis, Washington 1997

7. H. Renon, J.M. Prausnitz; AIChE J 14135 (1968)

8. D.S. Abrams, J.M. Prausnitz, AIChE J 21116 (1975)

9. D.F. Othmer, P.E. Tobias, Ind. Eng. Chem. 34690 (1942)

10. I. Bachman, Ind.Eng.Chem. Anal. Ed.12 38 (1940)

11. D.B. Hand, J.Phys.Chem. 341961 (1930) 